ЛАВРУХІН О. В., професор, д.т.н.,

БАУЛІНА Г. С., доцент, к.Т.Н.,

БОГОМАЗОВА Г. Є., асистент (Український державний університет залізничного транспорту)

\title{
Наукові підходи до вдосконалення технології експлуатації вантажних вагонів всіх форм власності
}

Запропонована оптимізаційна модель всього процесу пересування вагонів різних власників як у порожньому, так $і$ в завантаженому стані. Оптимальний варіант вибору кількості вагонів та їх форми власності для доставки вантажів від вантажсовідравника до вантажоодержувача визначається знаходженням мінімального значення сумарних експлуатаційних витрат і максимального прибутку залізниці.

Ключові слова: власні вагони, іноземні вагони, вагони власності залізниць, експлуатаційні витрати, продуктивність роботи вантажних вагонів, прибуток залізниць.

\section{Постанова проблеми}

Українські залізниці $є$ провідними у дорожньотранспортному комплексі України і забезпечують $82 \%$ вантажних перевезень, що здійснюються всіма видами транспорту. За обсягами вантажних перевезень залізниці України займають четверте місце на Свразійському континенті, поступаючись лише залізницям Китаю, Росії та Індії. Але на теперішній час ці перевезення зазнають великих змін. Якщо раніше упродовж багатьох років ця галузь отримувала прибуток за рахунок збільшення попиту і завдяки державним інвестуванням у розвиток інфраструктури й послуг, то зараз перспектива представляється в іншому світлі. Прогнозується, що ринок вантажних залізничних перевезень буде позиціонуватися слабким економічним зростом, стагнацією попиту, обмеженістю державних джерел фінансування та фундаментальними технологічними проривами на конкуруючих видах транспорту [1].

Для стабільного й стійкого зростання на ринку вантажних перевезень залізницям доведеться зміцнювати і розширювати свої позиції за рахунок модернізації транспортної системи [2]. Складність цього здійснення полягає в тому, що об'єкти транспортної інфраструктури, що перебувають у державній власності, потребують значних інвестицій і багато в чому залежать від фінансування 3 державного та місцевого бюджетів. Враховуючи недостатність фінансових коштів бюджету, необхідна взаємодія державного i приватного секторів й нові форми фінансування.

Основними завданнями 3 розвитку транспортної інфраструктури залізничного транспорту є збільшення пропускної здатності транспортної мережі й оновлення рухомого складу. Це дозволить суттєво поліпшити обслуговування споживачів транспорту, підвищити конкурентоспроможність Укрзалізниці на світовому ринку перевезень [3]. Поповнення вагонів, в більшій
\end{abstract}

мірі, здійснюється за рахунок транспортних компаній

власників рухомого складу, яких все більше з'являється на залізницях України.

Величезний ресурс збільшення транспортного потенціалу та обсягів перевезення приховується в удосконаленні управління вагонного парку всіх форм власності, а саме в зменшенні порожнього пробігу вагонів та покращенні їх обігу, скороченні терміну доставки вантажів. Ефективне використання вагонного парку надасть можливість для залізниці отримувати більший прибуток від вантажних перевезень, регулювати ціновий процес і задовольняти потреби клієнтів завдяки покращенню кількісних та якісних показників експлуатації рухомого складу.

\begin{abstract}
Аналіз останніх досліджень і публікацій
Задача продуктивного використання вагонів, що не належать українським компаніям, а також власних або орендованих вагонів, останнім часом стала однією 3 основних в експлуатаційній діяльності залізниць України. Цьому питанню присвячено ряд робіт. Так в дослідженнях [4-7] упор робиться на розвиток інформаційних технологій 3 організації перевезень парком вагонів операторських компаній, розглядаються підходи до автоматизованого обліку стану технічних засобів і прогнозування попиту на вантажні перевезення, розробляється організаційнотехнологічна модель управління парком вантажних вагонів різних форм власності 3 урахуванням пріоритетного обслуговування вантажовідправників, вантажоодержувачів. В роботі [8] розбирається оптимальна за вартістю задача регулювання порожніх вагонопотоків з урахуванням поділу вагонів на «свої» $\mathrm{i}$ «чужі», при цьому, не беруться до уваги експлуатаційні витрати інфраструктури та вартість перевезення навантаженого вагонопотоку.
\end{abstract}


() О.В. Лаврухін, Г.С. Бауліна, Г.Є. Богомазова, 2015 Формулювання цілей

Одним із напрямків дослідження в даній роботі $є$ удосконалення технології роботи вантажного вагонного парку на підставі оптимізації експлуатаційних витрат за кількісним показником використання рухомого складу та його форми приналежності, що приведе до збільшення прибутковості Укрзалізниці та залучення більшої кількості вантажопотоків на мережі залізниць.

Головним напрямком щодо покращення ефективності функціонування залізниць України $\epsilon$ оптимальний розподіл вагонопотоків на ділянках $\mathrm{i}$ напрямках мережі. Удосконалення технології роботи вагонного парку дозволяе більш ефективно використовувати основні фонди залізниць.

Підвищення продуктивності роботи парку вантажних вагонів робить його більш привабливим для користувачів залізничного транспорту. При цьому необхідно враховувати не тільки факт приналежності вагонів різним власникам, у тому числі залізницям країн СНД і Балтії, але і вартість самих вагонів, цінність вантажів, які в них перевозяться, а також терміни доставки і повернення іноземного рухомого складу на залізницю - власницю вагонів [9]. Прийняття ефективних регулювальних заходів щодо передислокації та раціональне використання парку іноземних вагонів на підставі теоретичних положень, дозволяе істотно знизити економічні витрати галузі, що викликані платежами за їх користування.

\section{Виклад основного матеріалу дослідження}

Експлуатаційна робота на кожній дирекції та залізниці має властиві імм особливості. Це пояснюється різними природними умовами, обсягом і структурою вантажів, розподілом іх за напрямками і за часом, технічною озброєністю та іншими факторами.

При дослідженні функціонування залізничної мережі був проведений аналіз існуючих технологій перевезення масових вантажів який довів, що перспективним напрямком реалізації перевезень цих вантажів $\epsilon$ така економічно доцільна $\mathrm{i}$ конкурентоспроможна технологія, при якій буде знайдено маршрут перевезення кожного вагону 3 мінімальними відстанями та мінімальними непродуктивними простоями при виконанні обов'язкової умови доставки всього вантажу до вантажоодержувача «точно у строк» в умовах існуючої кон'юнктури на транспортному ринку на період планування. Таким чином, впровадження гнучкої технології регулювання вагонним парком різних форм власності для перевезення масових вантажів потребує формалізації процесу перевезень на залізничній мережі у вигляді динамічної оптимізаційної задачі [10].
Нехай на мережі залізниць $\epsilon \quad m$ пунктів відправлення вантажів $\left(A_{1}, A_{2}, \ldots, A_{m}\right)$ з відповідними запасами вантажу $\left(a_{1}, a_{2}, \ldots, a_{m}\right)$ і $n$ пунктів призначення $\left(B_{1}, B_{2}, \ldots, B_{n}\right)$ з відповідними заявками на доставку вантажу $\left(b_{1}, b_{2}, \ldots, b_{n}\right)$. План перевезень вантажів повинен задовольняти вимогам відправника (всі запаси вантажу повинні бути вивезені) і потребам одержувача вантажу (всі заявки повинні бути задоволені), а загальна вартість перевезень повинна бути мінімальною. При цьому для якісного та своєчасного обслуговування вантажовідправників залізниця повинна забезпечувати підведення навантажувальних ресурсів на станції навантаження.

Раціональне переміщення вагонів на мережі залізниць для доставки вантажу зі станції навантаження до станції вивантаження, в тому числі підводу як порожніх вагонів до пунктів $\left(A_{1}, A_{2}, \ldots, A_{m}\right)$, так і завантажених під вивантаження на цих же пунктах під наступне навантаження, пропонується здійснювати на підставі визначення мінімального значення сумарних експлуатаційних витрат (оптимізаційна модель) за вибором кількості вагонів та їх форми власності для доставки вантажів від вантажовідправника до вантажоодержувача точно в строк.

Вибір оптимального плану регулювання вагонопотоків для перевезення вантажів в основному залежить від кількості та часу підведення порожніх вагонів на станції навантаження, часу навантаження вагонів, виду відправки, часу формування составу поїзда та часу доставки вантажу до вантажоодержувача. На рис. 1 представлена приблизна схема підведення рухомого складу до станцій навантаження та вивантаження, яка враховує вагони всіх форм власності. 


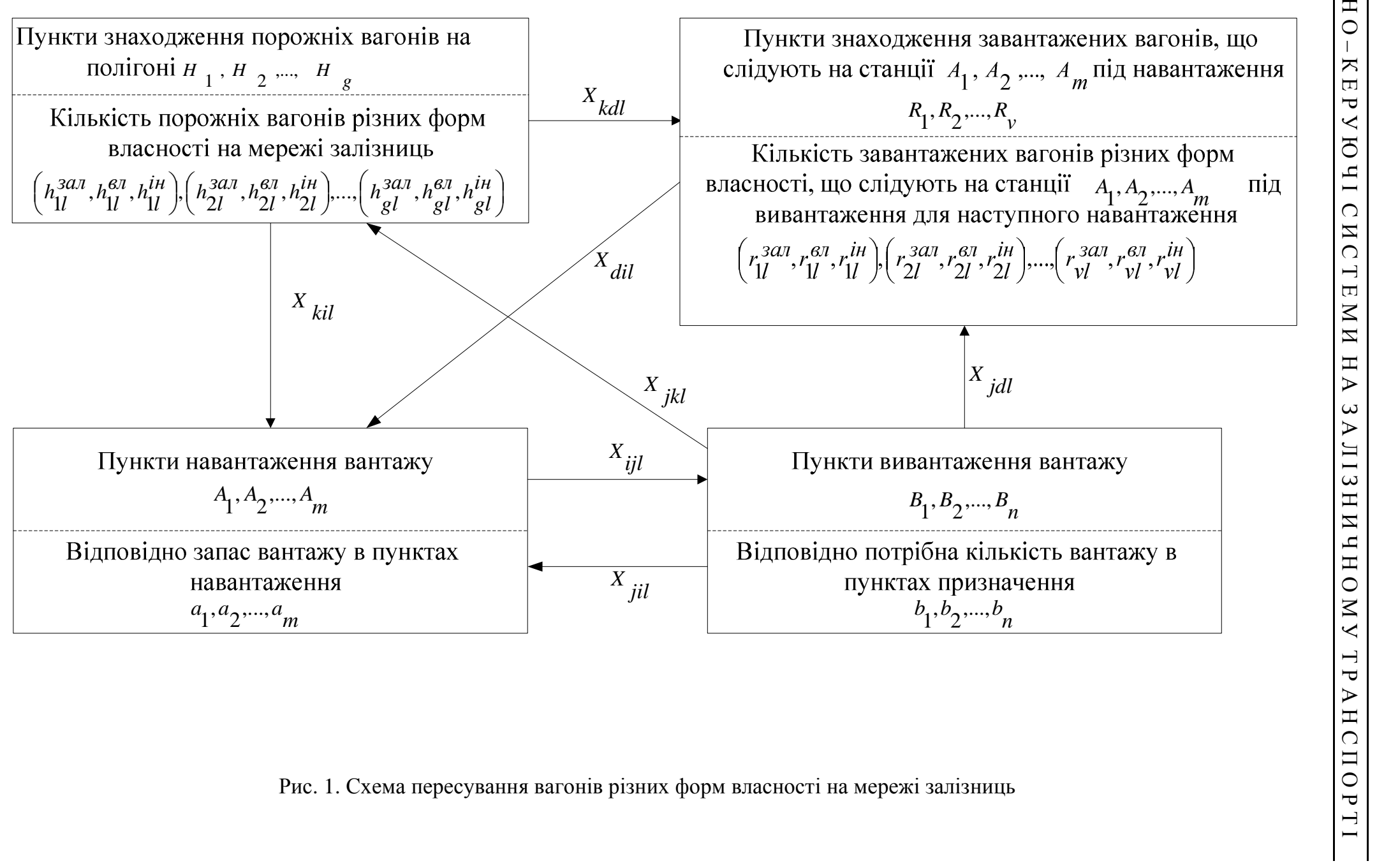


Так як вагони, що переміщуються по залізницях України, можуть бути трьох видів приналежності, то їх можна представити у вигляді матриці, яка складається з набору змінних моделі, що представлено нижче

$$
X=x_{i j}=\left(\begin{array}{lll}
x_{11} & x_{12} & x_{13} \\
x_{21} & x_{22} & x_{23} \\
\cdot & \cdot & \cdot \\
x_{m 1} & x_{m 2} & x_{m 3}
\end{array}\right),
$$

де $x_{i j}$ - множина наборів змінних моделі;

$i$ - станції відправлення вагонів, $i=\overline{1, m}$;

$j$ - показник приналежності вагона, $j=\overline{1,3}$.

При цьому:

$j=1$ для вагонів, що належать парку залізниць України;

$j=2$ для вагонів власних або орендованих;

$j=3$ для вагонів залізниць країн СНД та Балтії.

Вирішення питання оптимального регулювання вагонопотоків 3 урахуванням вагонів, що належать трьом групам власників, доцільно розглядати як задачу 3 подвійною оптимізацією: переміщення вагонів до станцій навантаження вантажу та розвезення вантажу.

У неявному вигляді цільова функція експлуатаційних витрат представлена формулою (2), при цьому функціонал $f\left(C_{i}\right),(i=\overline{1,8})$ має адитивний характер з восьми елементів, а величина $C_{i}$ - витрати по кожному елементу ланцюга постачання масового вантажу, які $€$ функцією кількості вагонів $X$ в напрямку станції вивантаження вантажу

$C_{I}(X)=\sum_{i=1}^{8} C_{i}(x) \rightarrow \min$,

де $X$ - змінна величина, що дорівнює кількості вагонів в одній відправці;

$C_{1}$ - витрати, що пов'язані з подачею вагонів до станцій навантаження масових вантажів $\left(A_{1}, A_{2}, \ldots, A_{m}\right)$

$C_{2}$ - витрати на навантаження вагонів в пунктах знаходження вантажу;

$C_{3}$ - витрати на маневрові операції в пунктах навантаження $\left(A_{1}, A_{2}, \ldots, A_{m}\right)$;

$C_{4}$ - витрати на станції примикання;
$C_{5}$ - витрати на шляху прямування;

$C_{6}$ - витрати на станції призначення;

$C_{7}$ - витрати на маневрові операції в пунктах вивантаження $\left(B_{1}, B_{2}, \ldots, B_{n}\right)$;

$C_{8}$ - витрати на вивантаження вагонів.

При цьому повинна виконуватись умова

$$
\begin{aligned}
& \left\{\begin{array}{l}
1 \leq X \leq \frac{a_{i}}{q_{c m}}, i \equiv \overline{1, n} ; \\
t_{\text {нав }}+t_{\text {форм }}+t_{\text {ши.прям }} \leq T ;
\end{array}\right.
\end{aligned}
$$

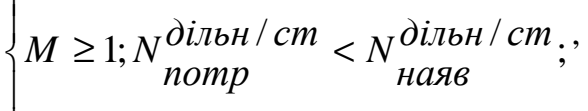

$$
\begin{aligned}
& Q_{\text {бр.лок }} \geq Q_{\text {бр.поїзда }} \text {; } \\
& X_{i}^{\Gamma P \Pi}=x_{i j}=X_{i}^{\Pi \Phi \Pi}
\end{aligned}
$$

де $a_{i}-$ кількість вантажу в $i$-тому пункті навантаження, т;

$q_{c m}$ - середнє статичне навантаження вагону, т;

$t_{\text {нав }}$ - час на навантаження $X$ вагонів;

${ }^{t_{\phi о р м}}$ - тривалість формування поїзда;

$t_{\text {u.прям }}$ - час знаходження поїзда на шляху прямування;

$T$ - строк доставки вантажу;

$M$ - кількість локомотивів;

$N^{\partial і л ь н / \mathrm{cm}}$ - потрібна пропускна спроможність nотр

відповідно дільниць та станцій;

$N_{\text {наяв }}^{\text {дільн } / \mathrm{cm}}$ - наявна пропускна спроможність відповідно дільниць та станцій;

$X_{i}^{\Gamma P П}-$ кількість вагонів за графіком руху поїздів;

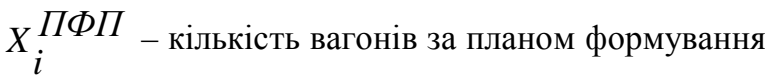
поїздів. 


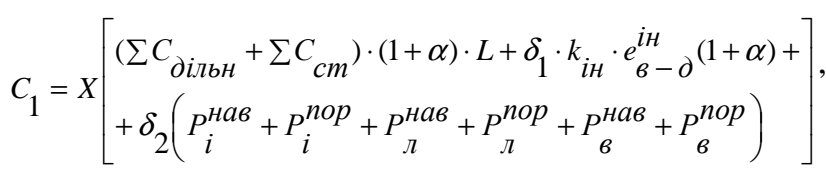

де $\sum C_{\text {дільн }}$ - сумарні витрати, що пов'язані 3 пропуском дільницею транзитних вантажних поїздів із навантажених та порожніх вагонів до станції навантаження;

$\sum C_{c m}-$ сумарні витрати, що пов'язані 3 пропуском транзитних вантажних поїздів із навантажених та порожніх вагонів на технічних станцій;

$\delta_{1}$ - коефіцієнт приналежності вагона ( $\delta_{1}=1$ для іноземного вагона, $\delta_{1}=0$ для українського вагона будь-якої власності);

$\delta_{2}$ - коефіцієнт власника вагона $\left(\delta_{2}=0\right.$ для іноземних вагонів, $\delta_{2}=1$ для українських вагонів);

$k_{i н}$ - коефіцієнт збільшення плати за іноземний вагон у залежності від часу знаходження його на українських залізницях;

$e_{B-\partial}^{i н}-$ плата за одну вагоно-добу знаходження іноземного вагону на залізницях України, грн./добу;

$L$ - відстань перевезення, км;

$\alpha$ - коефіцієнт порожнього пробігу вагонів (розрахований як відношення порожнього пробігу вагонів до пробігу навантажених вагонів);

$$
P_{i}^{\text {Haв }}, \quad P_{i}^{n o p}-\text { витрати на інфраструктурні }
$$

складові за початково-кінцеві операції (далі - ПКО) відповідно для навантаженого й порожнього вагонів;

$P_{\pi}^{\text {нав }}, P_{\pi}^{\text {nоp }}$ - витрати на локомотивні складові за ПКО відповідно для навантаженого й порожнього вагонів;

$P_{6}^{\text {нав }}, P_{6}^{n o p}$ - витрати на вагонні складові за ПКО відповідно для навантаженого й порожнього вагонів.

При визначенні вартості перевезень вантажів у власних вагонах локомотивами залізниць складові $P_{6}^{H a \beta}$ та $P_{6}^{n o p}$ не враховуються [11].

$C_{2}=C_{\text {в-2 }}+C_{\text {оч.в. }}$

де $C_{B-2}$ - вартість вагоно-години простою при виконанні вантажних операцій;
$C_{\text {оч.в. }}-$ витрати на очікування виконання вантажних операцій з вагонами.

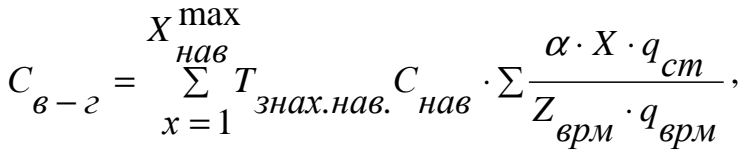

де $C_{\text {нав }}$ - вартість використання вагона у залежності від кількості годин простою вагонів під навантаженням $T_{\text {знах.нав, }}$, грн.;

$\alpha$ - частка участі навантажувального пункту в навантаженні вагонів однієї подачі;

$Z_{\text {врм }}$ - кількість вантажно-розвантажувальних машин на вантажному фронті;

$q_{\text {врм }}$ - продуктивність вантажнорозвантажувальної машини, т/год.

$C_{\text {оч.в. }}=\frac{\sum X_{\text {доб }}^{c e p}}{X} \cdot t_{\text {ов }} \cdot a_{B}$,

де $t_{o в}$ - час простою вагона в очікуванні виконання вантажних операцій;

$a_{B}$ - приведена вартість 1 вагоно-години простою, грн.

$C_{3}=t_{\text {под-приб }}^{\text {нав }} \cdot a_{\mathcal{M}} \cdot \frac{\Pi}{X}$

де $t_{\text {под-приб }}^{\text {нав }}-$ час на подачу-прибирання або переставлення вагонів на виставні колії

$a_{\mathcal{M}}$ - вартість 1 локомотиво-години маневрової роботи;

$\Pi$ - годинна експлуатаційна продуктивність вантажно-розвантажувальної машини або установки, вагонів за годину.

Витрати на станції примикання $C_{4}$ залежать від сумарного часу знаходження вагонів під накопиченням $\left(t_{\text {нак }}\right)$ на під’ізних коліях або у сортувальному парку станції, часу на формування состава, 3 урахуванням переставлення состава в парк відправлення ( $\left.t_{\text {форм }}\right)$, простою в парку відправлення $\left(t_{\text {ПВ }}\right)$ та часу знаходження вагонів під додатковими операціями 
$\left(t_{\text {дод }}\right) \quad$ (перевантажування, перевірка вантажу, очищення, промивання, пропарювання вагонів, обробка, екіпірування обладнання вагонів, а також переадресування чи перевідправлення вантажів за новими документами) помноженого на одиничну витратну ставку використання 1 км станційної інфраструктури протягом години $\left(C_{c m a н u}^{\kappa м / г о \partial}\right)$, що визначається в гривнях. Витрати на станції призначення $C_{6}$ залежать від сумарного часу простою вагонів на станції у парку прибуття $\left(t_{\Pi \Pi}\right)$, часу на розформування состава $\left(t_{\text {розф }}\right)$ та часу знаходження вагонів під додатковими операціями $\left(t_{\text {дод }}\right)$ помноженого на $C_{c m a \mu y}^{\kappa м / г о д . ~ A ~ в и т р а т и ~ н а ~ ш л я х у ~}$ прямування $C_{5}$ можна прийняти як операції у русі у вигляді

$C_{5}=X\left(\delta_{1} k_{i H} e_{B-\partial}^{i H} \frac{L}{S_{B}}+\delta_{2}\left(O_{i}+O_{\pi}+O_{\mathrm{B}}\right) \cdot L\right)$,

де $S_{B}$ - середньодобовий пробіг вагону, км;

$O_{i}$ - витрати на інфраструктурну складову за операції у русі (далі - ОР) за відправко-км;

$O_{л}$ - витрати на локомотивну складову за ОР за відправко-км;

$O_{B}$ - витрати на вагонну складову за ОР за відправко-км.

При визначенні вартості перевезень вантажів у власних вагонах локомотивами залізниць складова $O_{B}$ не враховується [11].

Витрати на маневрові операції в пунктах вивантаження $\left(B_{1}, B_{2}, \ldots, B_{n}\right) C_{7}$ можна визначити тим самим чином як і витрати на маневрові операції в пунктах навантаження $\left(A_{1}, A_{2}, \ldots, A_{m}\right) C_{3}$. Витрати на вивантаження вагонів $C_{8}$ визначимо за формулою (6), враховуючи при цьому вивантажувальні потужності вантажно-розвантажувальних машин або установок у пунктах призначення.

Доцільність використання іноземних вагонів може бути досягнута у тому випадку, якщо дохід від перевезення в ньому вантажу з пункту $A_{i}$ до пункту

$B$ буде не менше експлуатаційних витрат на переміщення порожнього вагона до пункту масового навантаження $\left(A_{1}, A_{2}, \ldots, A_{m}\right) \quad$ і далі вже $\mathrm{y}$ навантажувальному стані до пункту вивантаження $\left(B_{1}, B_{2}, \ldots, B_{n}\right)$. Математично такі обмеження можна записати у наступному вигляді

$$
D \cdot x_{i 3} \geq \sum_{i=1}^{8} C_{i} \cdot x_{i 3}
$$

де $D$ - дохід, що отримуємо 3 одного вагона при переміщенні його з пункту $A_{i}$ до пункту $B_{j}$.

\section{Висновки і перспективи дослідження}

На теперішній час представляється необхідним будь-яке управлінське рішення 3 регулювання пропуску вагонопотоків, а також різні варіанти організації вагонопотоків у поїзди і різні маршрути їх пересування оцінювати 3 точки зору впливу на кінцевий результат. Під останнім слід розуміти прибуток, одержаний від перевезення вантажів. При цьому варіанти організації вагонопотоків змінюють різні показники, за якими оцінюють діяльність залізничної галузі.

Найчастіше на практиці за перевагою того чи іншого показника приймається рішення, яке 3 точки зору «глобального» критерію (прибутку) не $\epsilon$ ефективним. Ось чому виникає необхідність в управлінні економічними результатами залізниці 3 урахуванням мінливих обсягів перевезень і в умовах конкурентної боротьби з іншими видами транспорту на ринку транспортних послуг 3 метою отримання максимального прибутку, а не поліпшення окремих експлуатаційних показників.

Для оцінки управлінських рішень на залізничному транспорті у сфері організації вагонопотоків 3 масовими вантажами будемо приймати за оптимальне рішення той випадок, коли залізниця буде отримувати найбільший прибуток.

В існуючих економічних умовах гарантією успішної роботи залізниць $є$ підвищення результативності транспорту за рахунок зниження експлуатаційних витрат. За безумовно оптимальний варіант приймається ситуація, при якій сумарні експлуатаційні витрати будуть прагнути до мінімуму при деякій кількості вагонів певної приналежності. Це надасть можливість вибору варіанта формування категорії поїзда, розрахувати раціональний час знаходження вагона в пунктах навантаженнявивантаження та на шляху прямування, своєчасну подачу вагонів до пункту навантаження у необхідній кількості. Для користувача послуг залізничного транспорту результат розрахунку оптимізаційної моделі дозволяє прискорити процес доставки вантажів, 
І Н Ф О Р М А І Й Н О-КЕ Р У Ю Ч С ИС Т Е И Н А З А Л З НИЧ Н О У Т Р АН С П О Р І

для сталевих магістралей - поліпшити показники використання основних фондів і підвищити прибутковість залізниць.

\section{Література}

1 Прогнозы развития европейского рынка грузовых перевозок [Текст] / Railway Gezette Internetional, 2014, № 9, p. 74-80; материалы компании McKinsey (www.mckinsey.com) // Железные дороги мира. - 2014. - № 11. - С.40-45.

2. Про схвалення Транспортної стратегії України на період до 2020 року [Текст] : розпорядження Кабінету міністрів України від 20 жовтня 2010 р. № 2174-р. - Київ // Урядовий кур'єр. - 2010. 22 груд. - С. 16.

3. Сергій Голосєєв. Максим Бланк [Текст] : «Укрзалізниця має стати клієнтоорієнтованою» / Сергій Голосєєв // Магістраль. - 2015. - 28 січн.3 лют. (№5 (1994)). - С. 3.

4. Данько, М. І. Формування вимог до технології взаємодії залізничних адміністрацій і власників рухомого складу [Текст] / М. І. Данько, Д. В. Ломотько, В. М. Запара, В. В. Кулешов // 3б. наук. праць. - Харків: УкрДАЗТ, 2011. Вип. 124 - С. 5-11.

5. Кулешов, В.В.Удосконалення інформаційної технології роботи 3 вагонами різних форм власності 3 метою оптимізації пропускної спроможності залізничних транспортних систем [Текст] / В. В. Кулешов // Зб. наук. праць. - Харків: УкрДАЗТ, 2011. - Вип. 124 - С. 83-90.

6. Данько, Н. И. Разработка организационнотехнологической модели управления парком грузовых вагонов разной формы собственности [Текст] / Н. И. Данько, Д. В. Ломотько, В.В. Кулешов // Инновационный транспорт. Екатеринбург: УрГУПС, 2012. - Ноябрь №4(5) C. 8-13.

7. Кулешов, В. В. Удосконалення технології перевезень парком вагонів операторських компаній на станціях вузла [Текст] / В.В. Кулешов, О. Ю. Толбатов, Т. Р. Чурилик // Зб. наук. праць. Харків: УкрДАЗТ, 2013. - Вип. 135 - С. 107-11.

8. Управление парками вагонов стран СНГ и Балтии на железных дорогах России : учебное пособие для вузов железнодорожного транспорта / В. И. Ковалев, С. Ю. Елисеев, А. Т. Осминин и др.; под ред. В.И. Ковалева, С. Ю. Елисеева, Е.Ю. Мокейчева. - М. : Маршрут, 2006. - 245 с.

9. Правила эксплуатации, пономерного учета и расчетов за пользование грузовыми вагонами собственности других государств [электронный pecypc]. С изм. и доп., принятыми на совещании уполномоченных представителей железнодорожных администраций 16.10 .1996 и на семнадцатом заседания Совета по железнодорожному транспорту 25.01.1997. Режим доступа: http://zakon2.rada.gov.ua/ laws/show/998 185. - Загол. с экрана.

10. Лаврухин, А.В. Усовершенствование регулирования парка грузовых вагонов разных собственников [Текст] / А.В. Лаврухин, А. Е. Богомазова // Логистическое управление грузо- и вагонопотоками. - Германия: Palmarium Academic Publishing, 2014. - Труды специалистов УкрГАЖТ. - С. $83-95$.

11. Методика розрахунку тарифів на перевезення вантажів залізничним транспортом [електроний ресурс]. Затверджено наказом Міністерства інфраструктури України 20.06.2013. № 418 Зареєстровано в Міністерстві юстиції України 27.06.2013 року за № 1082/23614. - Режим доступу: http://www.uz.gov.ua/cargo transportation/ legal_documents/metodyka/. - Загол. з екрану.

Лаврухин А.В., Баулина А.С., Богомазова А.Е. Научные подходы по усовершенствованию технологии эксплуатации грузовых вагонов всех форм собственности. Предложена оптимизационная модель всего процесса передвижения вагонов разных собственников как в порожнем, так и в груженом состоянии. Оптимальный вариант выбора количества вагонов и их формы собственности для доставки грузов от грузоотправителя к грузополучателю определяется нахождением минимального значения суммарных эксплуатационных затрат и максимальной прибыли железной дороги.

Ключевые слова: собственные вагоны, иностранные вагоны, вагоны собственности железных дорог, эксплуатационные затраты, продуктивность работы грузовых вагонов, прибыль железных дорог

Lavruhin O.V., Baulina G.S., Bogomazova G.E. Scientific approaches to improve the operation technology offreight wagonsof all the forms of ownership. Successful work of railways is estimated by the increase of the quantitative and qualitative indicators of the transportation process. The improvement of the effectiveness of transport is achieved by reducing operating costs, attracting customers and ensuring the competitiveness of transport. The optimization model of the whole movement process of wagons of different owners both loaded and empty is proposed in the article. The model takes into account various options to organize traffic volumes into trains and different routes of their movement, as well as the type of rolling stock and its form of ownership. Thanks to this, it becomes possible to select an option of train category, calculate the optimal a wagon 
residence time at loading and unloading points and on the travel line, deliver wagons timely to the loading point in the required quantity. The optimum alternative of wagon amount and ownership selection for the delivery of freights from the consignor to the consignee is determined by means of the identification of minimum value of total operating costs and maximum profit of railway.

Key words: own wagons, foreign wagons, wagons owned by railways, operating costs, productivity of freight wagons, profits of railway

Рецензент Огар О.М., д.т.н., професор, завідувач кафедри «Залізничні станції та вузли» (Український державний університет залізничного транспорту)

Поступила 11.06.20152.

Лаврухин А.В., профессор, д.т.н., Украинский государственный университет железнодорожного транспорта, Харьков, Украина.

Баулина А.C., доцент, к.т.н., Украинский государственный университет железнодорожного транспорта, Харьков, Украина.

Богомазова А.E., ассистент, Украинский государственный университет железнодорожного транспорта, Харьков, Украина.

Lavruhin O.V., professor, doct. of techn. sciences, Ukrainian State University of Railway Transport, Kharkiv, Ukraine.

Baulina G.S., docent, candidate of techn. sciences, Ukrainian State University of Railway Transport, Kharkiv, Ukraine.

Bogomazova G.E., assistant, Ukrainian State University of Railway Transport, Kharkiv, Ukraine. 